\title{
The Effect of Non-Compliance with Medication on Multidrug Resistant of Tuberculosis
}

\author{
Widya Kurnianingsih"), Didik Gunawan Tamtomo²), Bhisma Murti') \\ 1)Masters Program in Public Health, Universitas Sebelas Maret \\ 2)Faculty of Medicine, Universitas Sebelas Maret
}

\begin{abstract}
Background: Multidrug Resistant Tuberculosis (MDR-TB) is the biggest problem in the prevention and eradication of TB in the world. MDR TB exists in 27 countries where there are at least 6,800 MDR TB cases every year and $12 \%$ of new TB cases registered are MDR TB. MDR-TB is a disease caused by resistant Mycobacterium tuberculosis. This study aims to examine the effect of non-compliance with taking medication on the incidence of multidrug resistant tuberculosis (MDR TB).

Subjects and Method: The problems of this study with PICO are as follows: Population $=$ TB patients, Intervention $=$ Non-compliance with taking medication. Comparison $=$ Adherence to taking medication, and Outcome $=$ Incidence of Multidrug Resistant Tuberculosis. Meta- analysis was carried out by systematically reviewing articles from Google Scholar, Pubmed and Springer Link. The articles used in this research are articles that have been published from 2010-2019. The keywords to look for articles are as follows: "Risk Factor MDR TB" OR "Previous Treatment" AND "Multidrug resistant tuberculosis". The inclusion criteria used were full paper, used English, case control study

design and the results reported were adjusted odds ratio. Articles were collected using the PRISMA diagram and analyzed using the Review Manager 5.3 application with a fixed effect model.

Results: A total of nine articles reviewed in this study came from Bangladesh, Malaysia, Pakistan and Ethiopia. This resulted in a study showing that the effect of incomplete treatment increased the risk of multidrug resistant tuberculosis $(\mathrm{aOR}=10.04 ; 95 \% \mathrm{CI}=8.90$ to $11.32 ; \mathrm{p}$ $<0.001)$.

Conclusion: The effect of incomplete treatment increases the risk of multidrug resistant tuberculosis in Taiwan, Bangladesh, Malaysia and Ethiopia.

Keywords: Effect of incomplete treatment, Multidrug resistant tuberculosis (MDR TB)

\section{Correspondence:}

Widya Kurnianingsih. Masters Program in Public Health, Universitas Sebelas Maret. Jl. Ir. Sutami 36A, Surakarta 57125, Central Java. Email: widyakurnianingsiho8@gmail.com. Mobile: 081556837033 .
\end{abstract}

Cite this as:

Kurnianingsih W, Tamtomo DG, Murti B (2020). The Effect of Non-Compliance with Medication on Multidrug Resistant of Tuberculosis. J Epidemiol Public Health. 05(04): 442-450. https://doi.org/10.26911/jepublichealth.2020.05.04.06.

cc) (i) (2) Journal of Epidemiology and Public Healthis licensed under a Creative Commons EY NC SA Attribution-NonCommercial-ShareAlike 4.o International License.

\section{BACKGROUND}

Pulmonary tuberculosis (pulmonary TB) is still a public health problem in the world, although control efforts with the Direct Observed Treatment Shortcourse (DOTS) strategy have been implemented in many countries since 1995. Multidrug Resistant Tuberculosis (MDR-TB) is a the biggest problem in the prevention and eradication of TB in the world, given the difficult and costly treatment (Utomo, 2017).

Tuberculosis (TB) is one of the top ten causes of death worldwide. WHO reported that between 2013 and 2017 there was an increase in pulmonary TB cases from 9 million cases to 10 million cases (WHO, 2018). TB cases have caused 1.6 million deaths. WHO in 2018 reported 7 
countries with the most TB cases, namely India, Indonesia, China, the Philippines, Pakistan, Nigeria and South Africa (WHO, 2018).

Globally, MDR TB cases were detected as many as 161,000 cases, $29 \%$ of the estimated 558,000 cases in 2017, an increase compared to 2016, which were 153,119 cases detected (WHO, 2018). MDR TB causes patients to have to repeat the anti-tuberculosis (OAT) drug treatment from the beginning with more expensive costs (100 times), more toxic drugs, and a longer time using second-line drugs, besides that the results are not necessarily satisfactory 2010). Many factors contribute to drug resistance in developing countries (Sarwani et al., 2012). Inadequate MDR TB treatment is known to be the main cause both in terms of regimen, dose and duration of therapy so that it affects the cure rate for MDR TB patients (Pratama, 2011).

The low prevalence of MDR-TB was estimated at $0.2 \%$ among new TB cases and 6.1\% among previously treated and since then TB sufferers have shown a progressive increase from year to year. The most recent national survey conducted in 2008 indicated that MDR-TB was 2.5\% among new cases and 5.5\% among previously treated TB cases (Gamino et al., 2014). The prevalence of MDR pulmonary TB is influenced by. Factors that contribute to drug resistance in developing countries include the patient's ignorance of the disease, poor patient adherence, administration of monotherapy or drug regimens that are ineffective, inadequate doses, poor instruction, low medication regularity, poor patient motivation, insufficient drug supply. regularly, drug availability and drug quality contribute to secondary drug resistance, it is very important to reduce the burden, to decide health priorities and to allocate resources (Mekonnen et al., 2015).
Malnutrition and tuberculosis are serious problems and are the most left behind in the world (1). Malnutrition increases the risk of multidrug resistant tuberculosis (MDR TB) and nutritional status is a major determinant of morbidity and mortality due to multidrug resistant tuberculosis. Multidrug resistant tuberculosis affects the metabolism of essential nutrients such as protein and some micronutrients. Malnutrition on the other hand limits cell-mediated immunity and increases susceptibility to infection. This causes nutritional stress and weight loss, thereby reducing the body's ability to fight infection (weakens immune function) and nutritional status (Bhargava et.al 2014). A systematic review showed a strong association between malnutrition (defined as a low body mass index [BMI]) and the incidence of MDR TB, and concluded that low BMI is a risk factor for developing MDR TB (Bragava et.al 2014). Several studies reported that patients with active TB were more likely to be thin or have a lower body mass index $\left(\mathrm{BMI}=\mathrm{kg} / \mathrm{m}^{2}\right)$ than healthy controls and was associated with increased mortality in MDR TB patients. Nutritional deficiencies can delay recovery by impaired immune function. So that good nutrition will be able to improve recovery in people being treated.

WHO (2014) states that if TB sufferers do not comply with taking anti-tuberculosis drugs, the final result of concern is the failure of TB cure coupled with the emergence of TB germs that are resistant to tuberculosis drugs. The results of the analysis in this study indicate that there is a direct relationship between patients taking tuberculosis drugs and the incidence of MDR TB. That states that the most dominant factor that can affect the incidence of MDR TB is non-compliance with 
tuberculosis patient treatment (Hirpa et.al 2013).

\section{SUBJECTS AND METHOD}

\section{Study Design}

This research is a systematic review and meta-analysis. The articles used in this study were obtained from several databases including PubMed, Google Scholar, and Science Direct. Keywords for searching articles are as follows: risk incomplete medicine treatment "OR" nutritional status ") AND" Multidrug resistant tuberculosis ". "Risk factor multidrug resistant", "incomplete medicine treatment factor multidrug resistant tuberculosis", "Nutrition status of multidrug resistant tuberculosis risk factor".

\section{Inclusion Criteria}

Articles included in this study must be full paper, case control study design and in English. The article must be appropriate wherein it is tested the independent variable of medication non-adherence to the incidence of multidrug resistant tuberculosis, based on a multivariate analysis of the adjusted odds ratio.

\section{Exclusion Criteria}

The articles published in this study are not in English. The articles are articles whose result is not the adjusted Odss Ratio. As well as the number of research samples (n $<100$ ).

\section{Operational Definition}

The article search was carried out by considering the eligibility criteria defined using the PICO model. The population in the study was tuberculosis patients with intervention in the form of non-adherence to taking medication, comparison of adherence to taking medication and outcomes in the form of multidrug resistant tuberculosis.

\section{Data Analysis}

Data processing was carried out by the Review Manager (RevMan 5.3) by calculating the effect size and heterogeneity to determine which research models were combined and formed the final metaanalysis result.

\section{RESULTS}

The article review process can be seen in the PRISMA flow diagram in Figure 1. Figure 2 shows the areas where articles were taken according to the inclusion criteria. This meta-analysis analyzes 9 primary studies conducted on 2 continents, namely the African Continent (Ethiopia), the Asian Continent (Bangladesh, China, and Pakistan).

Assessment of the quality of the primary studies was carried out quantitatively and qualitatively. This research uses Critical

Appraisal Checklist for Case-Control Study sourced from the Center for Evidence Based Management (CEBMa, 2014).

Based on the assessment of the quality of the primary articles above, the score for the quality of the articles is 11 to 12 . This indicates that the articles are of good quality for meta-analysis (CEBMa, 2014).

A summary of the primary articles used for the meta-analysis of the effect of incompleteness taking medication on the incidence of multidrug resistant tuberculosis can be seen in Table 3 . 
Kurnianingsih et al./ Non-Compliance with Medication on Multidrug Resistant of Tuberculosis

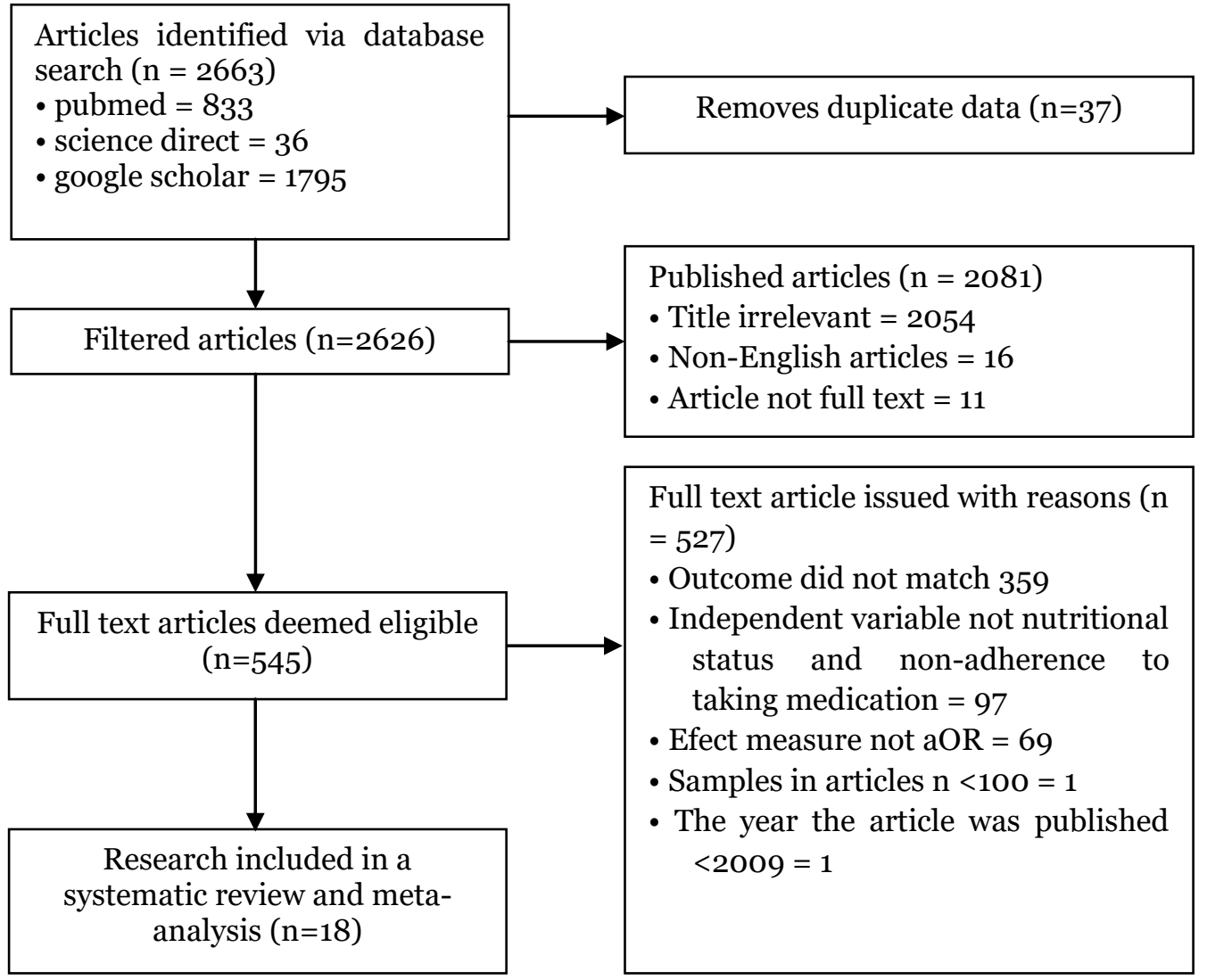

\section{Figure 1. PRISMA Flow Diagram}
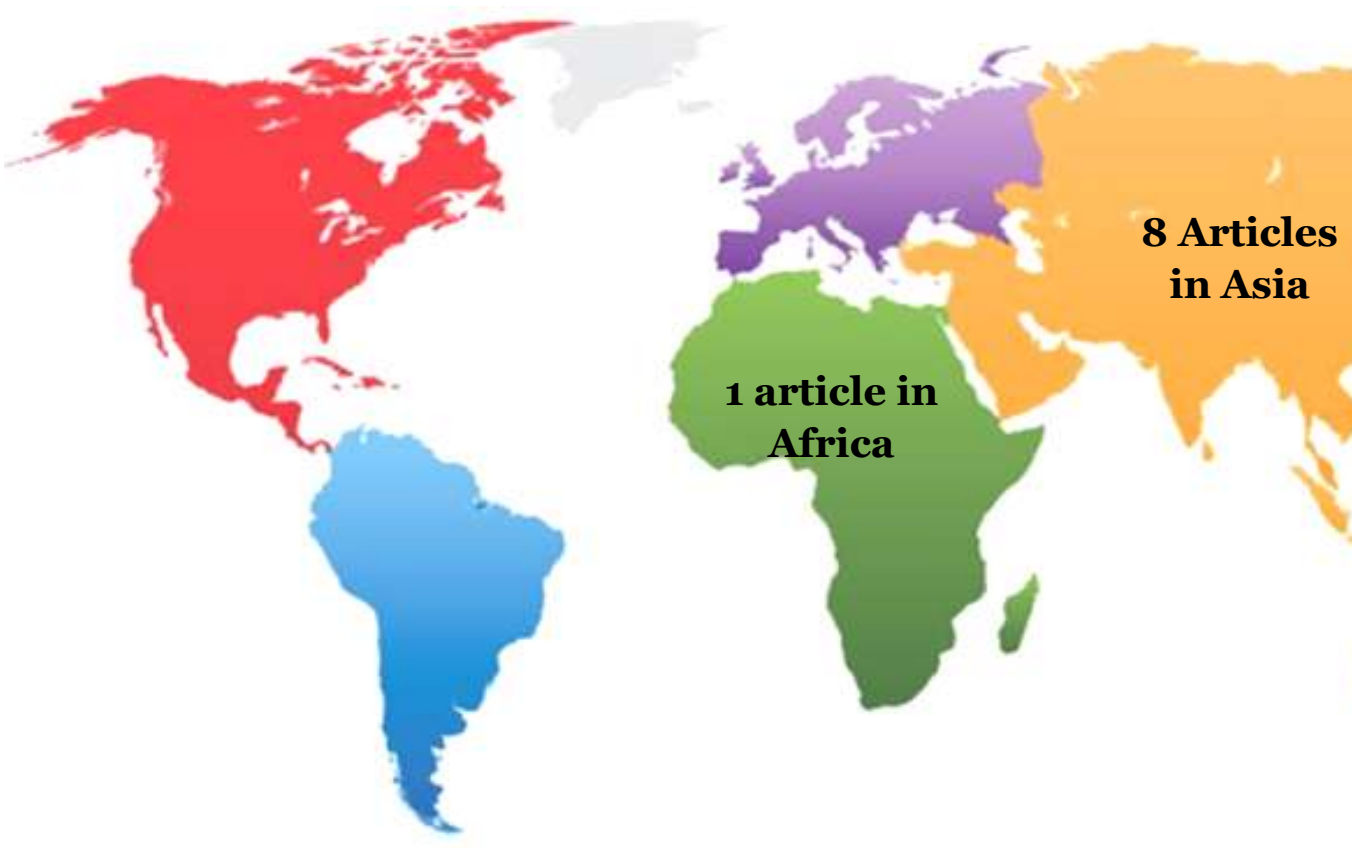

Figure 2. Map of the research area 
Kurnianingsih et al./ Non-Compliance with Medication on Multidrug Resistant of Tuberculosis

Table 3. Descriptions of primary studies included in the meta-analysis

\begin{tabular}{|c|c|c|c|c|c|c|c|}
\hline Author (year) & County & $\begin{array}{l}\text { Desain } \\
\text { Studi }\end{array}$ & Sampel & $\begin{array}{c}\mathbf{P} \\
\text { (Population) }\end{array}$ & I (Intervension) & C (Comparison) & O (Outcome) \\
\hline $\begin{array}{l}\text { Tong lv et al., } \\
2018\end{array}$ & China & $\begin{array}{l}\text { Case } \\
\text { Control }\end{array}$ & 3552 & $\begin{array}{l}\text { Tuberculosis } \\
\text { patient }\end{array}$ & $\begin{array}{ll}\begin{array}{l}\text { Obediently } \\
\text { medicine }\end{array} & \text { take }\end{array}$ & $\begin{array}{l}\text { Not obedient to taking } \\
\text { medicine }\end{array}$ & Incidence of MDR TB \\
\hline Tombo et al 2019 & Botswana & $\begin{array}{l}\text { Case } \\
\text { Control }\end{array}$ & 2568 & $\begin{array}{l}\text { Tuberculosis } \\
\text { patient }\end{array}$ & $\begin{array}{l}\text { Complete taking } \\
\text { medication }\end{array}$ & Incomplete medication & Incidence of MDR TB \\
\hline Elmi et al 2016 & Malaysia & $\begin{array}{l}\text { Case } \\
\text { Control }\end{array}$ & 314 & $\begin{array}{l}\text { Tuberculosis } \\
\text { patient }\end{array}$ & Obey taking medicine & $\begin{array}{l}\text { Not obedient to taking } \\
\text { medicine }\end{array}$ & Incidence of MDR TB \\
\hline Wang et al 2013 & China & $\begin{array}{l}\text { Case } \\
\text { Control }\end{array}$ & 111 & $\begin{array}{l}\text { Tuberculosis } \\
\text { patient }\end{array}$ & Obey taking medicine & $\begin{array}{l}\text { Not obedient to taking } \\
\text { medicine }\end{array}$ & Incidence of MDR TB \\
\hline $\begin{array}{l}\text { Workicho et al } \\
2017\end{array}$ & Ethiopia & $\begin{array}{l}\text { Case } \\
\text { Control }\end{array}$ & 180 & $\begin{array}{l}\text { Tuberculosis } \\
\text { patient }\end{array}$ & $\begin{array}{l}\text { Complete taking } \\
\text { medication }\end{array}$ & Incomplete taking medication & Incidence of MDR TB \\
\hline Rifat et al 2015 & Bangladesh & $\begin{array}{l}\text { Case } \\
\text { Control }\end{array}$ & 250 & $\begin{array}{l}\text { Tuberculosis } \\
\text { patient }\end{array}$ & $\begin{array}{l}\text { Complete taking } \\
\text { medication }\end{array}$ & Incomplete taking medication & Incidence of MDR TB \\
\hline Dessica et al 2017 & Ethiopia & $\begin{array}{l}\text { Case } \\
\text { Control }\end{array}$ & 255 & $\begin{array}{l}\text { Tuberculosis } \\
\text { patient }\end{array}$ & Obey taking medicine & $\begin{array}{l}\text { Not obedient to taking } \\
\text { medicine }\end{array}$ & Incidence of MDR TB \\
\hline Mulisa et al 2015 & Ethiopia & $\begin{array}{l}\text { Case } \\
\text { Control }\end{array}$ & 349 & $\begin{array}{l}\text { Tuberculosis } \\
\text { patient }\end{array}$ & Obey taking medicine & $\begin{array}{l}\text { Not obedient to taking } \\
\text { medicine }\end{array}$ & Incidence of MDR TB \\
\hline Ahmad et al 2019 & Pakistan & $\begin{array}{l}\text { Case } \\
\text { Control } \\
\end{array}$ & 125 & $\begin{array}{l}\text { Tuberculosis } \\
\text { patient }\end{array}$ & Obey taking medicine & $\begin{array}{l}\text { Not obedient to taking } \\
\text { medicine }\end{array}$ & Incidence of MDR TB \\
\hline
\end{tabular}


Kurnianingsih et al./ Non-Compliance with Medication on Multidrug Resistant of Tuberculosis

\section{a. Forest Plot}

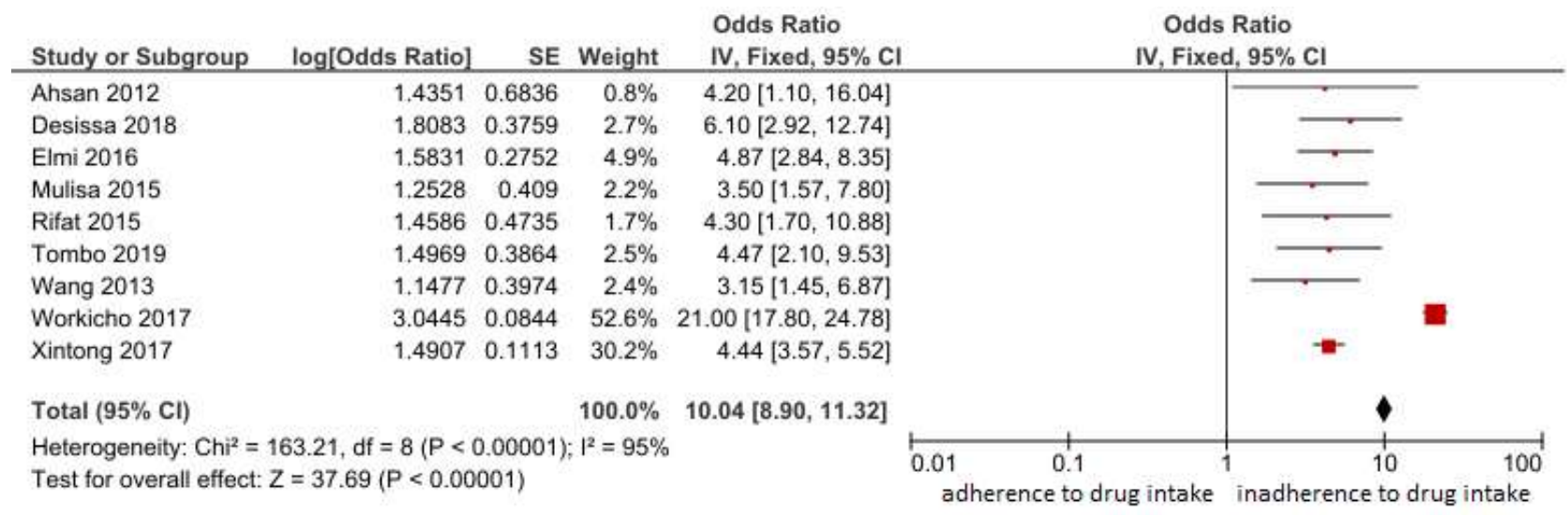

\section{Figure 3. Forest plot the effect of non-compliance with taking medication on the incidence of multidrug resistant tuberculosis}

Based on the results of the forest plot (Figure 3), non-adherence to taking medication would have an effect on the incidence of multidrug resistant tuberculosis by 1.04 times compared to patients who were adherent taking medication against the incidence of b. Funnel Plot multidrug resistant tuberculosis and statistically significant ( $\mathrm{p}<0.001)$. The heterogeneity of the research data showed $\mathrm{I}^{2}=95 \%$. So that the distribution of data is declared heterogeneous (random effect model).

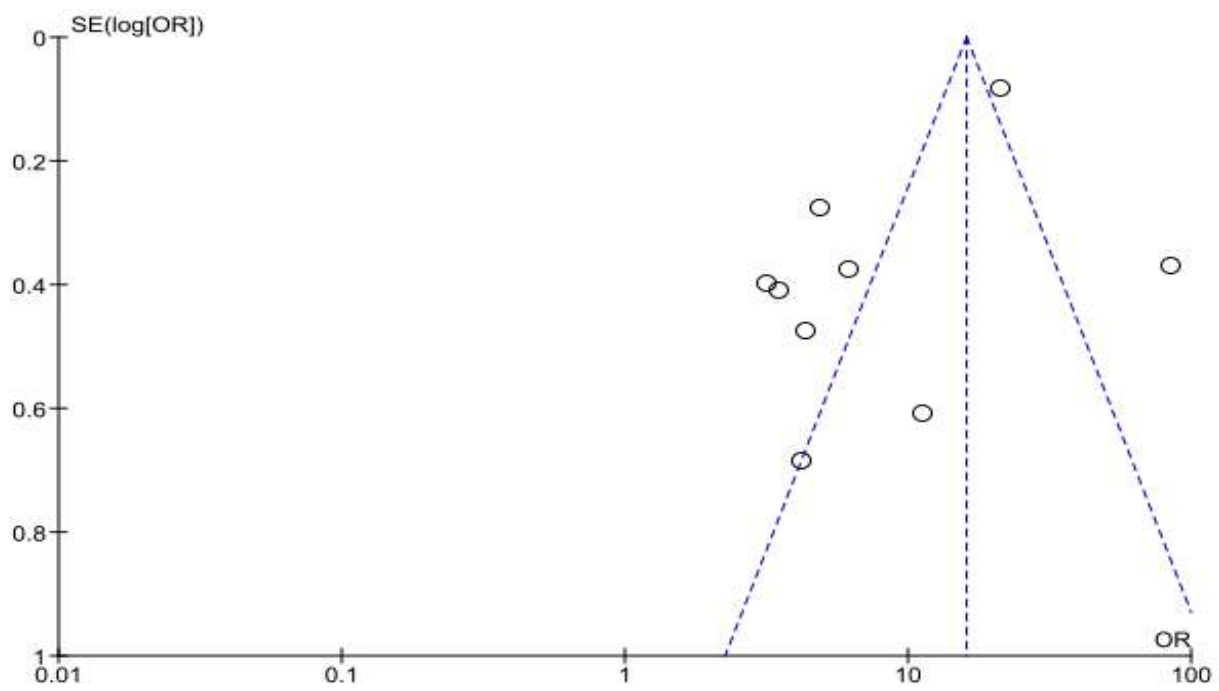

Figure 4. Funnel plot the effect of non-compliance with taking medication on the incidence of multidrug resistant tuberculosis

Figure 4 shows that some of the primary studies used have an asymmetrical distribution of plots, where 2 plots are on the right side and 7 plots are on the left.
The plot on the right side of the graph appears to have a standard error between 0.0 and 0.4 , while the plot on the left has a standard error between 0.2 and 0.7. This 
Kurnianingsih et al./ Non-Compliance with Medication on Multidrug Resistant of Tuberculosis

indicates that there is a publication bias in the study.

\section{DISCUSSION}

This systematic study study and metaanalysis raised the theme of the effect of non-adherence to medication on the incidence of multidrug resistant tuberculosis. This meta-analysis study used research sources that controlled for confounding factors or confounding factors which could be seen from the study inclusion requirements, namely multivariate analysis and the statistical results reported were adjusted odds ratio (aOR). The combined results of the effect of non-compliance with taking medication on the incidence of multidrug resistant tuberculosis were processed using the RevMan 5.3 application, while the results of the systematic study and metaanalysis were presented in the form of a forest plot and a funnel plot.

Treatment adherence is important to avoid MDR TB and treatment failure. Patient adherence is highly demanded in undergoing this long-term treatment. Adherence to taking this medication is needed in all diseases, especially tuberculosis, which requires extra supervision in its treatment (Nurismi, 2014).

The results of this study are in accordance with Fauziah (2013), which shows that MDR TB sufferers are more frequent in respondents who are not adherent to treatment than those who are adherent. Patients who were not adherent had a 10.8 times chance of developing MDR TB compared to patients who were adherent to their treatment.

\section{AUTHOR CONTRIBUTION}

Widya is the main researcher who chooses topics, explores and collects research data. Didik Tamtomo and Bhisma Murti played a role in analyzing data and reviewing research documents.

\section{CONFLICT OF INTEREST}

There is no conflict of interest in this study.

FUNDING AND SPONSORSHIP

This study is self-funded.

\section{ACKNOWLEDGEMENT}

We are grateful to the database providers PubMed, Science Direct and Google Scholar.

\section{REFERENCE}

Bhargava A, Benedetti A, Oxlade O, Pai M, Menzies D (2014). Undernutrition and the incidence of tuberculosis in India: National and subnational estimates of the population attributable fraction related to undernutrition. Natl Med J India. 27(3): 128-33. PMID: 25668081.

Botswana Ministry of Health. National Tuberculosis Control Program Combined Annual Report 2013 - 2014. Ministry of Health, Republic of Botswana, Gaborone.

Ding P, Li X, Jia Z, Lu Z (2017). Multidrug resistant tuberculosis (MDR-TB) disease burden in China: A systematic review and spatio-temporal analysis. BMC Infectious Diseases, 17(57): 130. https://dx.doi.org/10.1186\%2Fs12879-016-2151-5.

Fauziah LA (2013). Faktor-faktor yang berpengaruh terhadap kejadian Tuberculosis Multidrug Resistant (TBMDR) di RSUP Persahabatan Tahun 2013 (Factors that influence the incidence of Multidrug Resistant Tuberculosis (TB-MDR) in Friendship Hospital in 2013), Jakarta, Universitas Indonesia. 
Gelaw SM (2016). Sosioeconomic factors associated with knowledge on tuberculosis among adult in Ethiopia. Tuberculosis Research and Treatment. 11. https://doi.org/10.1155/20$16 / 6207457$.

Hirpa S, Medhin G, Girma B, Melese M, Mekonen A, Suarez P, Ameni G (2013). Determinants of multidrugresistant tuberculosis in patients on first-line treatment in Addis Ababa: A case control study. BMC Public Health. 13(782): 1-9. https://doi.org/10.1186/1471-2458-13-782.

Kementerian Kesehatan RI. Infodatin Tb (2015). Infodatin Tuberkulosis. 2015. Available from: http://dinkes.sulselprov.go.id/file/publik/Data ProfilL 2015.pdf.

Masniari L, Priyanti ZS, Tjandra YA (2007). Faktor-faktor yang mempengaruhi kesembuhan penderita TB paru (Factors that influence the recovery of pulmonary TB sufferers). Jurnal Respiratori Indonesia, 27(3): 176-183.

Mekonnen F, Tessema B, Moges F, Gelaw A, Eshetie S, Kumera G (2015). Multidrug resistant TB: prevalence and risk factors in the West Metema and Armachiho districts. BMC Infect Dis. 15: 461. https://doi.org/10.1186/s12879-015-1202-7.

Menzies HJ, Moalosi G, Anisimova V, Gammino V, Sentle C, Bachhuber MA, et al. (2014). Increase in anti-tuberculosis drug resistance in Botswana: results from the fourth National Drug Resistance Survey. Int J Tuberc Lung Dis. 18(9):1026-33. https://doi.org/10.1186/s12879-015-1202-7.

Murti B (2018). Prinsip dan metode riset epidemiologi (Epidemiological Research Principles and Methods). Edisi ke 5. Surakarta: Program Studi Ilmu Kesehatan Masyarakat.
Nurhayati I, Kurniawan T, Mardiah W (2015). Perilaku pencegahan penularan dan faktor-faktor yang melatarbelakanginya pada pasien Tuberculosis Multidrug Resistance (TB MDR) (Transmission prevention behavior and the factors behind it in patients with multidrug resistance tuberculosis (MDR TB)). Jurnal Keperawatan Padjajaran, 3 (3), 166-175

Nurismi (2014). Faktor-faktor yang berhubungan dengan terjadinya multi drug resistant pada pasien tuberculosis paru terhadap penyembuhan di Poliklinik TB-MDR RSUD Labuang Baji Makasar 2013 (Factors associated with the occurrence of multi drug resistant in pulmonary tuberculosis patients to recovery in MDR-TB Polyclinic Labuang Baji Makassar Hospital 2013). Makasar, Universitas Hasanuddin.

Pratama GB. (2011). Faktor-faktor yang mempengaruhi terjadinya resistensi rifampicin dan isoniazid pada pasien tuberkulosis paru di BKPM Semarang (Factors that influence the occurrence of rifampicin and isoniazid resistance in pulmonary tuberculosis patients at BKPM Semarang). 1-24

Patiung F, Wongkar MCP, Mandang V. (2014). Hubungan status gizi dengan CD4 pada pasien TB paru (Relationship between nutritional status and CD4 cell count in pulmonary $\mathrm{TB}$ patients). Jurnal e-Clinic, 2(2), 1-7

Putri FA, Burhan E, Nawas A, Soepandi PZ, Sutoyo DK, Agustin H, Isbaniah F (2014). Body mass index predictive of sputum culture conversion among MDR-TB patients in Indonesia. Int $\mathrm{J}$ Tuberc Lung Dis. 18(5): 564-570. https://doi.org/10.5588/ijtld.13.0602

Safri FM, Sukartini T, Ulfiana E (2014). Analisis faktor yang berhubungan 
dengan kepatuhan minum obat pasien TB paru berdasarkan Health Belief Model di Wilayah Kerja Puskesmas Umbulsari, Kabupaten Jember (Analysis of factors related to medication adherence to pulmonary tuberculosis patients based on the Health Belief Model in the Umbulsari Community Health Center, Jember Regency). Indonesian Journal of Community Health Nursing. 2(2): 12-20. http://dx.doi.org/10.20473/ijchn.v2i2.11904.

Sarwani D, Nurlaela S, Zahrotu I (2012). Faktor resiko multidrug resistant tuberculosis (MDR TB) (Risk factors for Multidrug Resistant Tuberculosis (MDR TB). Jurnal Kesehatan Masyarakat. 8(1): 60-66. https://doi.org/10.15294/kemas.v8i1.2260.

Vera V (2018). A path analysis on the risk factors of multidrug resistant tuberculosis in Surakarta, Central Java. Mid-International Conference on Public Health 2018. https://doi.org/10.26911/mid.icph.2018.01.02.

Skrahina A, Hurevich H, Zalutskaya A, Sahalchyk E, Astrauko A, Hoffner S, Rusovich V, et al. (2013). Multidrug resistant tuberculosis in Belarus: The size of the problem and associated risk factors. Bulletin of the World Health Organization. 91(1): 36-45. https://dx.doi.org/10.2471\%2FBLT.1 2.104588 .

Susilaningtyas F (2010). Faktor risiko kejadian Multi Drug Resistant pada pasien TB Paru di Balai Besar Kesehatan Paru Masyarakat (BBKPM) (Risk factors for the incidence of Multi Drug Resistant in pulmonary TB patients at the Center for Community Lung Health (BBKPM)) Surakarta.

Tola HH, Shojaeizadeh D, Tol A, Garmaroudi G, Yekaninejad MS, Kebede A,
Ejeta LT, et al. (2016). Psychological and educational intervention to improve tuberculosis treatment adherence in Ethiopia based on health belief model: A cluster randomized control trial. PLoS ONE, 11(5): 1-15. https://doi.org/10.1371/journal.pone. 0155147.

Tripathi KD (2013). Essentials of Medical Pharmacology. 7th ed. New Delhi: Jaypee Brothers.

Utomo GC, Joebagyo H, Murti B (2017). Case Study on Multi-Drug Resistance Tuberculosis in Grobogan, Central Java. J Epidemiol Public Health. 2(3): 186-200. https://doi.org/10.26911/jepublichealth.2017.02.03.01.

Wijaya AA (2012). Merokok dan tuberculosis (Smoking and tuberculosis). Jurnal Tuberculosis Indonesia. 8: 1823.

Wokas JAJ, Wongkar MCP, Surachmanto E (2015). Hubungan antara status gizi, sputum BTA dengan gambaran rotgen paru pada pasien tuberculosis (The relationship between nutritional status, sputum AFB with lung X-rays in tuberculosis patients). Jurnal eClinic. 3(1): 298-305. https://doi.org/10.35790/ecl.3.1.2015.6833.

World Health Organization (2017). Multydrug resistant tuberculosis (MDRTB).

World Health Organization (2018). World TB Day 2018 Campaign.

Zhang C, Wang Y, Shi G, Han W, Zhao H, Zhang H, Xi X (2016). Determinants of multidrug-resistant tuberculosis in Henan Province in China: A case control study. BMC Public Health, 16(42):1-9. https://doi.org/10.1186/s12889-016-2711-z. 